\title{
THE TECHNIQUES OF UPBRINGING SYMBOLISM AND THEIR APPLICATION IN PUBLIC COMMUNICATION
}

\begin{abstract}
ANNA ALEKSANYAN
From the point of view of communicology ${ }^{1}$, due to social interaction, upbringing is a social challenge that is based on communication impact and corresponds to it, and it includes not only education system. In the context of changes in contemporary social processes, where a person is shaped and developed, the study and the application of new potential of upbringing is of particular importance. Moreover, influences of upbringing exist in the society also spontaneously and are important for the observation of their possibilities in terms of revealing the strategic impacts of public communication. As we can clearly state in a modern information society, where the undeniable influences of information flows are emphasized, the sources and forces of new influences of upbringing are out of scope of both family and education system and are beyond control. Nowadays, families' and schools' traditional pedagogical forces and "room" effects are gently weakened, and the role of the realities of "life pedagogy" is increased.
\end{abstract}

Methodological bases of the theory of upbringing. Throughout history in the process of personality formation, both the inherent factor and the external influences - the social environment, especially the upbringing or all the factors together, have always been important ${ }^{2}$. However, it has always been undeniable that the development of a person is impossible without the upbringing realized in the social environment. "Upbringing is the most important component of human being's social essence - the system of values, desires, interrelations, choices and meaning of life and behavior..." ".

As John Amos Comenius notes "Becoming a man is possible only through

${ }^{1}$ Cooley C. H. Social organization: A study of the larger mind. New York, NY: Charles Scribner's Sons, 1909; Craig R. T. Communication Theory as a Field. Communication Theory. 1999, 9 (2), pp. 119-161; Richard L. L. The Human Science of Communicology. Duquesne University Press. 1992; Isaac E. C., Deborah Eicher-Catt. Communicology: The New Science of Embodied Discourse. Fairleigh Dickinson Univ Press, 2010.

${ }^{2}$ Adler A. The individual psychology: A systematic presentation of selection from his writings. H.L. \& R.R. Ansbacher (Eds.). New York: Basic Books, 1956; Bandura A. Social cognitive theory of self-regulation. Organizational Behavior and Hman Decision Processes, 1991, Hillsdate, pp. 248-287; Fromm E. The sane society. New York: Rinehalt, 1955; Fromm E. The sane society. New York: Rinehalt, 1955; Sullivan H.S. The interpersonal theory of psychiatry. New York: Norton, 1953; Watson D.L., Tharp R. G. Self-directed behavior: Self-modification for personal argument. Pacific Grove, CA: Brooks/Cole. The stormy decade: fact of fiction, "Psychology in the School", 1, 1989, pp. 224-231.

${ }^{3}$ Столяренко А.М. Общая педагогика: Учеб. пособие для студ. вузов по педагогическим специальностям. М.: Изд. "ЮНИТИ-ДАНА”, 2006, с. 211. 
upbringing..."4 . Based on this, he considers the purpose of education as "bringing up a person", the implementation of which is principally possible, in case the child undergoes different forms of communication.

J.A. Comenius highlights, paying particular attention to the upbringing process, it can be divided into three levels". On the first level, the child "recognizes the surrounding world and himself", what he can do only through communication with different people and in different relations. On the second level, "there is shaped capability to control not only personal behavior, but also others' actions", which is only possible after the acquisition of certain competences of inner-personal and interpersonal communication, where re-educational and selfregulatory issues are raised. The third and the most important degree, according to Comenius, is available only to the person who passed the first two steps of upbringing, in which there is an "aspiration to God" (the book was written in the Middle Ages). The last level, interpreted in contemporary professional terms, can be stated as an aspiration to conscious perfection and mental selfsufficiency. From professional educational point of view, it is of particular interest to self-excel, which is possible due to self-analysis and critical thinking, self-evaluation, continuous and long improvement, creativity, etc.

The source of development of upbringing is centuries-old practice, experience that is based on lifestyle, traditions, customs, national schools, as well as philosophical, pedagogical, psychological, social studies, global and national experiences of the time, innovative approaches and ideas, current challenges and ambitions of subsequent generations.

The researches on upbringing are classified as basic schools and directions in social sciences. The following directions are of particular importance, i.e. liberal and natural upbringing (J.-J. Rousseau ${ }^{6}$, L. Tolstoy ${ }^{7}$ ), humanistic and existential upbringing also known as person-centered education (A. Maslow ${ }^{8}, \mathrm{C}$. Rogers $^{9}$, E. Fromm ${ }^{10}$, V. Frankl ${ }^{11}$, L. Vygotsky ${ }^{12}$ and others).

The first two directions have led to heated discussions over time. The most

4 Коменский Я.А. Избранные педагогические сочинения. М.: Гос. учебнопедагогическое издательство министерства просвещения РСФСР, 1955, с. 204.

5 Коменский Я.А. Избранные педагогические сочинения. М.: Гос. учебнопедагогическое издательство министерства просвещения РСФСР, 1955.

${ }^{6}$ Rousseau J.-J. Emile, or On Education. Trans. Allan Bloom. New York: Basic Books, 1979.

7 Толстой Л.Н. Сборник статьей. Пособие для учителя. М.: Гос. учебнопедагогическое издательство министерства просвещения РСФСР, 1955, с. 32.

8 Maslow A.A. Theory of Human Motivation. Psychological Review, 1943, Vol. 50, No4, pp. 370-396.

${ }^{9}$ Rogers C. and Stevens B. Person to Person: The Problem of Being Human. Lafayette, CA: Real People Press. 1967; Rogers C, Lyon H. C. \& Tausch R. On Becoming an Effective Teacher-Person-centered Teaching, Psychology, Philosophy, and Dialogues with Carl R. Rogers and Harold Lyon. London: Routledge. 2013.

${ }^{10}$ Fromm E. Socialist Humanism, 1965; Fromm E. The Revolution of Hope, toward a humanized technology, 1968; Fromm E. On Being Human. 1997.

${ }^{11}$ Frankl V. The Will to Meaning. Foundations and Applications of Logotherapy, New American Library, New York, 1988.

${ }_{12}$ Выготский Л.С. Психология развития ребенка. М.: Изд. “Эксмо”, 2005. 
common and justified one is the direction of humanistic upbringing, which was formed parallel to the Renaissance humanism and humanistic psychology. Representatives of this direction put human capabilities, interests and aspirations in the center of upbringing, self-assertion, self-regulation and self-organization in socialization and social relations. The emphasis of humanistic upbringing is based on tolerance, mutual understanding, mutual trust, on the person and his perception of life as a high value, as well as fundamental human rights and freedoms. The result of humanistic education is a humanist itself.

Graph 1

The structure matrix of upbringing at the public communication level.

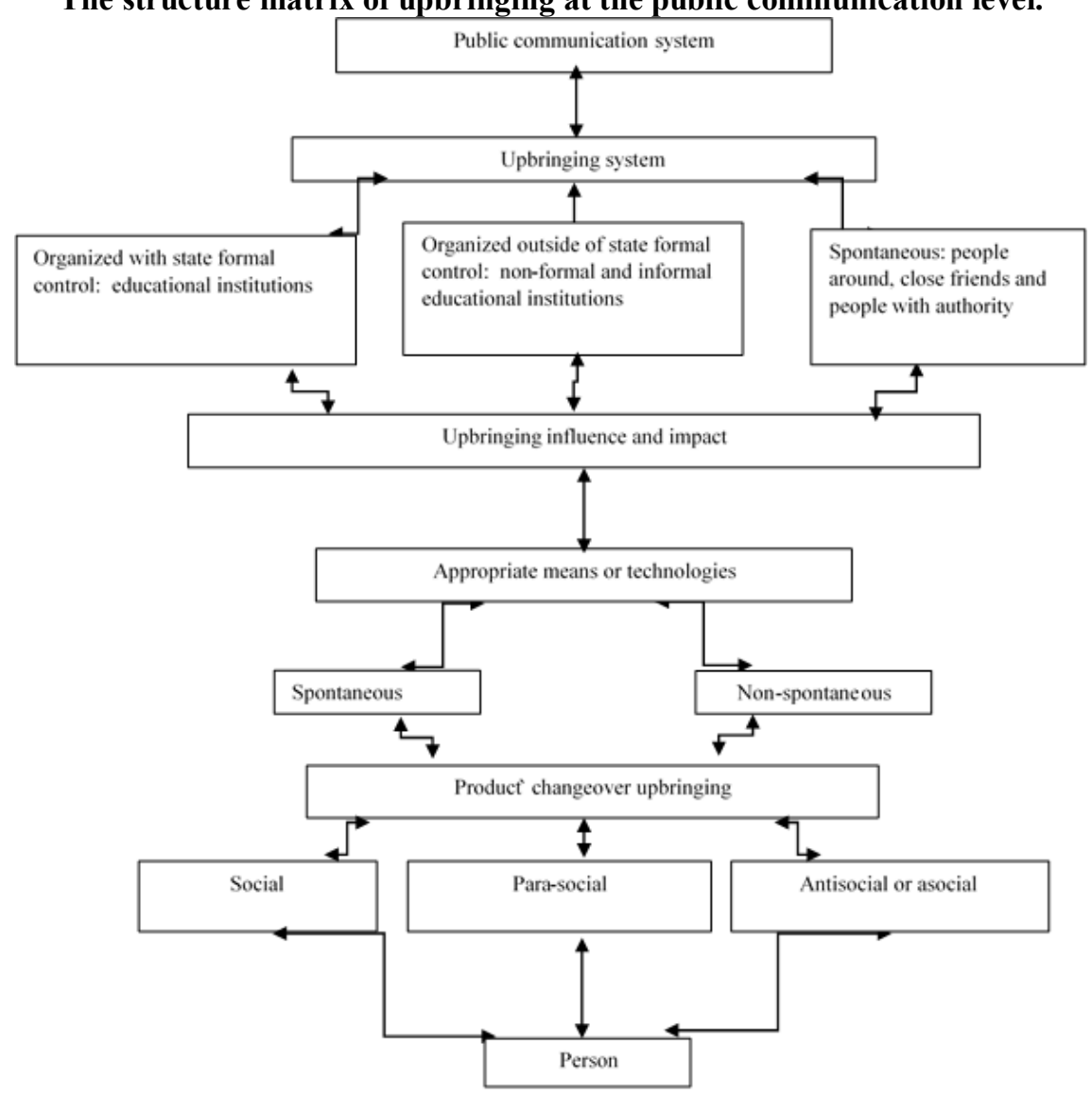

Especially in the 20th century and since then, the individual author schools have begun to develop and upbringing techniques as well. Since then, most of the eminent scholars are considered to be J. Piaget ${ }^{13}$, M. Montessori ${ }^{14}$, A. Makarenko ${ }^{15}$, R. Steiner ${ }^{16}$, J. Dewey ${ }^{17}$ and other's upbringing systems.

${ }^{13}$ Piaget J. The Child's Conception of the World. London: Routledge and Kegan Paul, 1928. Piaget J. The construction of reality in the child (New York: Basic Books, 1954.

${ }^{14}$ Montessori M. Education for a New World. Kalakshetra, 1947.

${ }_{15}^{15}$ Макаренко А.С. Коллектив и воспитание личности. М.: “Педагогика”, 1972.

${ }_{17}^{16}$ Штайнер Р. Познания человека и учебный процесс. М.: Изд. "Парсифаль”, 1998.

${ }^{17}$ Dewey J. Experience and Education, Kappa Delta Pi, N.Y., 1938. 
The features of aspects and all directions of upbringing, as well as the peculiarities of individual author schools, are conditioned by the influences undertaken by the educators and changed upbringing. The system of these influences, including the integrity of methods, tools, ways, programs, as well as the projected outcomes constitute the technique basis for the upbringing process. This technique base allows the public processes to have an educational implications on the public by applying proper technology elements which lead to certain results. This is counterbalanced to learning process that is organized exclusively in educational institutions and requires paper-kind certification as an educational outcome, but in the case of upbringing there is no such requirement and cannot be at all.

The process of upbringing, unlike the learning process, can also be spontaneous, as well as it can exist self-willingly. From this perspective, the matrix of upbringing has a rather interesting structure (Graph 1 ) at the public communication level.

\section{Symbolism of upbringing: visualization of upbringing as a technique.} Symbolism of upbringing has come along with thinking and language. Symbolism of upbringing is a reflection of upbringing in different phenomena of social life.

The first fairy tales, sayings, and stories, which were told for educational purposes, were worked out concrete image and forms, thus creating the model of upbringing. At that time, we can say, that symbolism of upbringing took place intuitively or spontaneously.

The theoretical background and frameworks of symbolism of upbringing are going back to the very beginning of Renaissance with the art-educational movement. At that time every phenomena included education, learning and upbringing in society that had to be reflected in the virtuous art forms and vice versa, getting their own image.

Nowadays, in modern society, the art is not the only way of creating the image and forms of education and upbringing. There are a range of fields of public communication in modern society, where we can observe different ways of symbolism of education and upbringing. The most observed way is the visualization of upbringing, which can be defined as the technique of public communication.

We can say that one of the manipulation spheres of public communication is the symbolization of upbringing in order to control social consciousness. There are methodological bases of symbolism of reality in society which are coming from the theories of A. Schulz ${ }^{18}$ (Problem of motivation in attitude and

${ }^{18}$ Schulz A. Symbol, Reality, and Society, in Schulz A. Collected Papers. V.I. The Problem of Social Reality, Dordrecht, Kluwer Academic Publishers, 1962. 
their symbolism in society), H. Blumer ${ }^{19}$ (Symbolic Interactionism), G. Mead ${ }^{20}$ (The symbols are experience according to which the minds and identities are shaped during social interactions), N. Elias ${ }^{21}$ (Personal interactions are the sources of meanings of symbols), L.M. Killian ${ }^{22}$ (Collective behavior and its characters), T. Parsons ${ }^{23}$ (The system of personal actions and their changes are determined by "Expressive symbolism" and by social and cultural systems of social transmitters: money, control, impact, values, etc.) and others.

These theories let us conclude, the attitude of a person and groups is constructed and changed in accordance with the characters around, as a result of Symbolic Interactions. And continuing this idea, we can state, that upbringing can mainly have an impact on the behavior of a person or mass, because the definitions of upbringing approve, that upbringing is a social process during which oriented influences are directed to the persons aimed at changing their attitude with different means and ways. Especially, upbringing theories give us the concept of shaping consciousness through their own methods.

Visualization of upbringing can be defined as upbringing influences through communication expressions and demonstrations or the shaping of upbringing through communication means and characters.

This is a very special definition and covers the entire content of upbringing visualization.

Upbringing visualization is specific through communication expressions and demonstrations, moreover education becomes tangible and more concrete even available for sensory perception.

In the context of public communication, the forms of "presentation" of upbringing are more interesting in the process of upbringing visualizations. From this perspective, it is not so much about what or who the author is and source of the visualization of upbringing, but it is about the impact on the growing generation, on the masses and how to apply it in different situations as visualization of upbringing is situational.

Upbringing visualization creates a unique field of education, in which the representatives of growing generations are influenced by various impacts. This field of education can be created in both formal and non-formal education frameworks (see Graph 2).

${ }^{19}$ Blumer H. The Methodological Position of Symbolic Interactionism, in Blumer H. Symbolic Interactionism. Perspective and Method. Berkeley: University California Press, 1969, p. 1.

${ }^{20}$ Mead G. Mind, Self and Society. From the Standpoint of a Social Behaviorist. Chicago: The University of Chicago Press, 1934. P. 122.

${ }_{21}^{21}$ Elias N. The Symbol Theory. London, Sage, 1991, p. 40. 1957.

${ }^{22}$ Turner R., Killian L.M. Collective Behavior. Englewood Cliffs, N.J.: Prentice-Hall,

${ }^{23}$ Parsons T. The social system, New York, The Free Press, 1951: Chapter IX. Expressive Symbols and the Social System. The Communication of Affect, pp. 384-427. 
Educational fields for symbolism of upbringing.

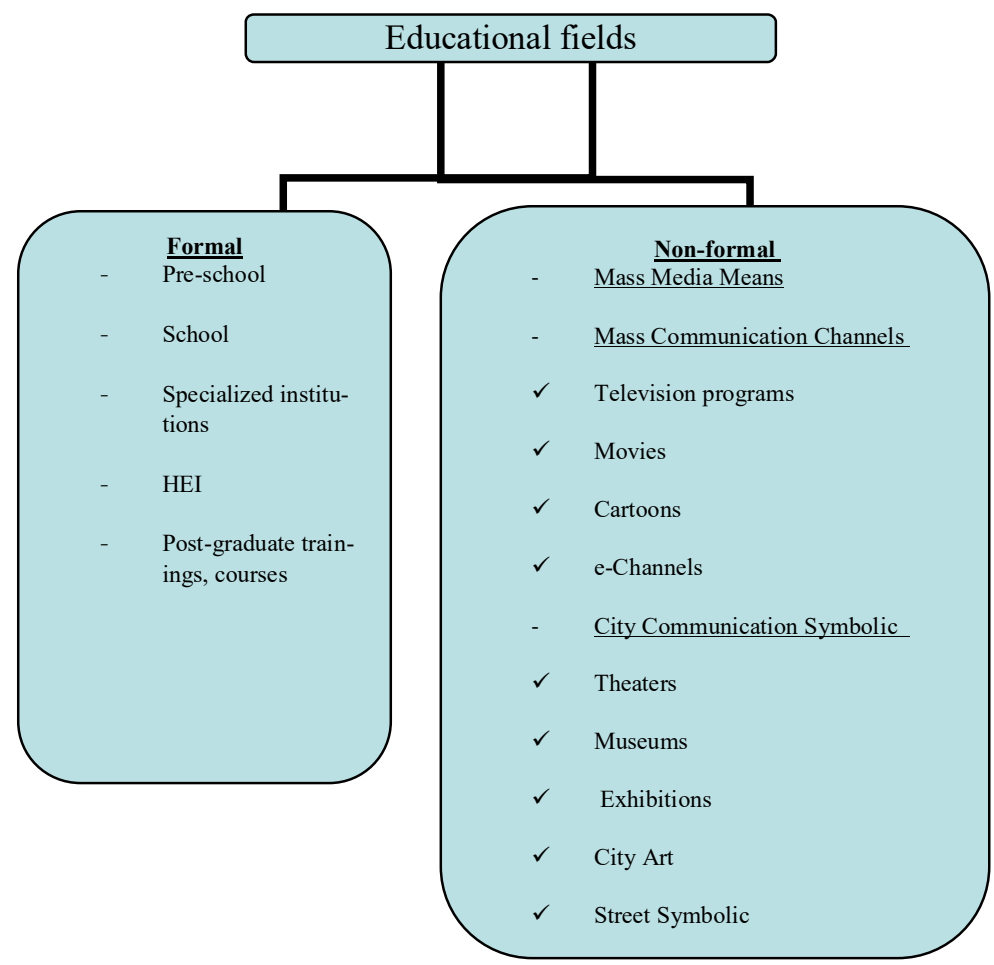

The advantages and disadvantages of upbringing visualization. Visualization of upbringing has a number of features in formal and non-formal educational fields. Hence, the advantage of visualization in formal educational field is insured against the negative elements, because here it passes through the visualization model of upbringing and is liberated from various negative components. On the other hand, however, the negative components are, in turn, highly conditional for the certain period, region and society. That is, they can be transformed into positive with the time.

Besides, there is a negative aspect in the formal education field, i.e. the restriction and strong borders. Having passed those same models of upbringing, visualization of upbringing must meet certain criteria that limit and do not allow representatives of rising generations to get acquainted with all the aspects of phenomena and upbringing visualization. It should be noted, however, that in pedagogy there is such a notion that upbringing can be not only positive, but also negative. This means that part of the visualization of upbringing in the formal educational field remains open. Unfortunately, the missing part is very large, because today within the ranges of information society, the information obtained from mass media, particularly the Internet is becoming more interesting and comes to fill that gap.

That is why the influence of non-formal education on the representatives 
of today's growing generation is even greater. Upbringing visualization is carried out by the non-formal educational system and is poorly coordinated or presented as "non-systemized". In all cases, the danger of non-formal education lies in the fact that interest in it is increasing day by day, and today it is easier for people to have influence on others, to formulate specific feelings and experiences. Of course, this process goes out of control.

Transfer of social experience by means of public communication as the construction of educating reality. Upbringing visualization and the effective organization of influences through it are possible only if the practitioner or acting subject has sufficient and appropriate experience. This social experience has the effect of reality construction for the effective upbringing and socialization of a person.

From this point of view, not only the social experience of the influencing subject is important, but also the perception and internalization of this experience by the representatives of the rising generation on the level of world outlook, actions and thinking. In order to internalize this experience, it is necessary for the student to let himself apply it in practice.

In any case, each person has an experience that is transmitted to him from the elder generations by various means (fairy tales, stories, proverbs, cartoons, films, street arts and other means). Another question is: What does this experience contain? The experience can be both effective-positive and also negative, in its perceptions and expressions. The interests of people, their background and the events taking place around the world condition it.

Not only education, but also everyday life, events and various phenomena related to a person are the source of social experiences. From this perspective, social experience is mediated, where new experiences always come to distinguish and re-interpret the experience.

Some authors believe that our social experiences are the expectations we have on the way to world-wide recognition, which is the basis for our communicative integral comments. It is the key for all kinds of cultural experiments and innovations.

Peculiarities of Social Experience Formation. As an educating reality, social experience is formed in social institutions. This formation occurs spontaneously or indirectly, and vice versa, purposefully and directly. Some public institutions have direct and indirect impacts. "Person can be developed in two main ways: through identification and social dynamics" ${ }^{24}$.

All social institutes, such as family, education, religion, cultural institutions, political and economic institutions, sufficiently and necessarily influencing on the human educating reality contribute to the formation of social experience components.

Formation of social experiences begins with the following:

\footnotetext{
${ }^{24}$ Холл К.С., Линдсей Г. Теории личности. М.: Изд.“ЭКСМО-Пресс”, 1999, с. 56.
} 
1. Formation of identity, which begins with the primary socialization institutions in the family or substitute;

2. Formation of interests where not only family members, but also all social institutions of the society have their contribution;

3. The formation of behavioral norms, influencing social institutions, especially religion and culture;

4. Adjusting the relationships that all public institutions contribute to shaping a value system that has occurred mainly in education processes.

In other words, the mechanisms of formation of social experiences are five: shaping identity, developing interests, forming behavioral norms, regulating relations and forming a value system. It means that in order to have an impact on the formation or modification of social experiences, it is important to pay particular attention to the all above-mentioned mechanisms.

Stereotypes of upbringing as forms of perception and expression of social experience. The perception of social experience, as it has already been pointed out, begins from family fairy tales, traditions, customs, cultural components, beliefs, embracing different moral norms that begin with shaping the identity, when the child begins to identify himself with these phenomena. Because of their permanent repetitions, there are formed models of behavior and self-expression, mental schemes, repetitive perceptions about the world, i.e. all together are going to make stereotypes.

Stereotypes in this case are viewed from the educational point of view as ways of perceiving and manifesting social experiences. Stereotypes are more common and characteristic for conservative or closed societies. They find their expression in folklore, literary works, artwork, and mass media, disseminating and finding their way through the world outlook in a variety of ways.

Stereotypes often determine the peculiarities of social experiences. That is why special attention is given to stereotypes in the process of upbringing visualization.

The components of the social experience, which are explored on the bases of various studies, are as follows:

$\circ$ Attention to scenes and events that generate interest and satisfaction and at the same time relate to world-acquaintance.

- The curiosity, interest and appeal.

- Cognizance and emotional resonance with specific phenomena.

○ Linking your own emotions and emotions to the world's perception (not just pleasant, but also disturbed and overwhelming), that is to say, we are not indifferent to what we have and to what we have caring attitude.

- Perceptions of phenomena that can cause stress or admiration. Ability to solve problems.

○ Subjective and personal experiences gained during perception and cognition of the world.

○ Traditions, what is commonplace and acceptable for the person, what 
moves the human imagination and what identifies the person.

○ How do the world's trends and processes reflect on human perceptions, as well as accumulation of social experiences?

- Human capacity and prerequisites, which are the basis for new experience.

- The degree of consciousness of social experimentation, as well as the understanding of the connection with culture and art.

- Understanding the enrichment of esthetic experience through communication.

- Obtaining information that contributes to the construction of educating reality.

Formation of social experience through upbringing does not pursue the goal of shaping feelings related to upbringing. That is to say, the purpose of public communication is not simply to get acquainted with upbringing, moreover, it is not about to form positive emotions. The goal is to formulate or visualize the upbringing through the means that build up the educating reality for different purposes, which affect the growing generations. It is important to take into account that any social experience has two directions: sensual perceptions and feelings.

Graph 3

The system structure of upbringing symbolism.

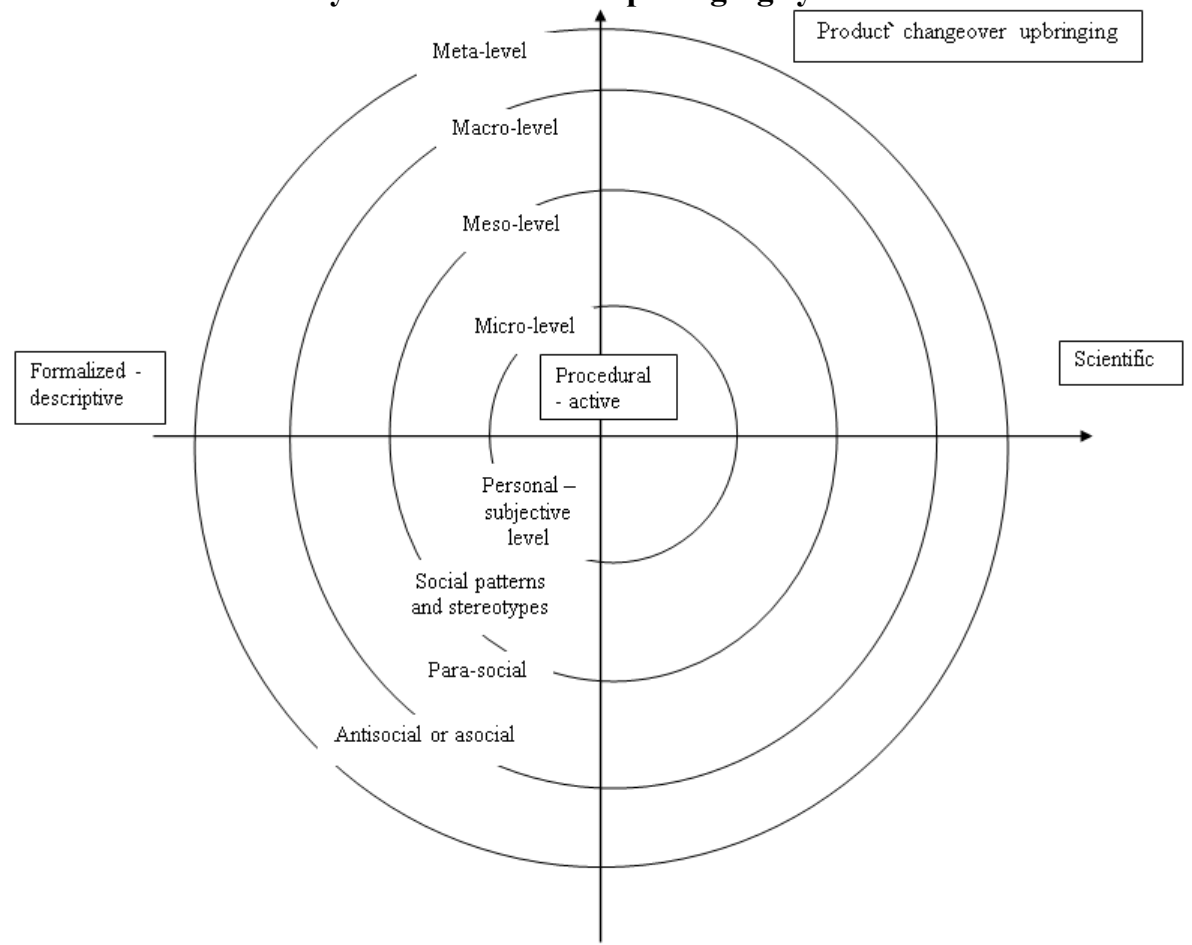

In conclusion, we can state that visualization of upbringing, as a technique of symbolism of upbringing, is taking place in society, which acts spontaneously in non-formal field of education and aim-directed way in formal field. Each field of education has its own ways, methods and programs for the outcomes of upbringing symbolism in society. This technique can be defined also 
as public communication technique, because it includes all mass communication means, social networks, institutions and public fields.

Key words: upbringing symbolism, visualization of upbringing, techniques of visualization, public communication

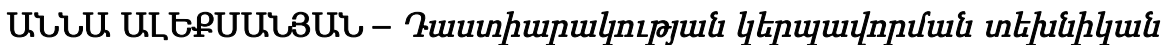

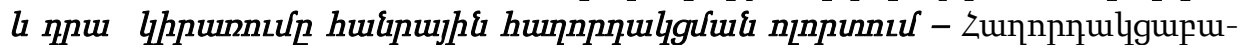

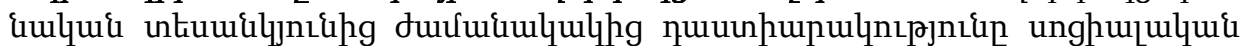

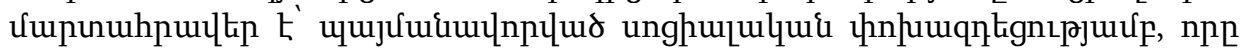

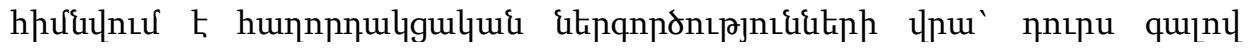

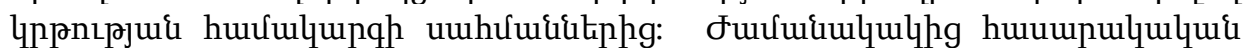

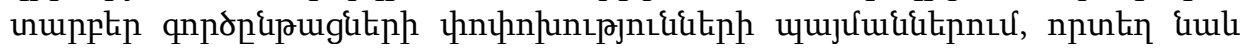

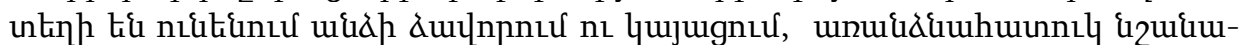

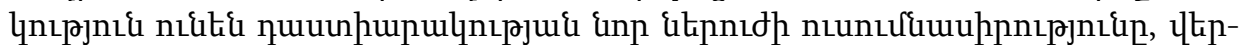

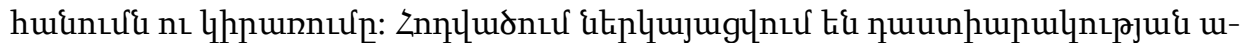

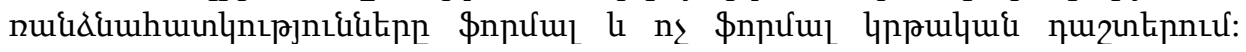

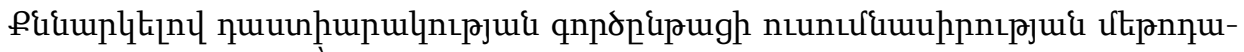

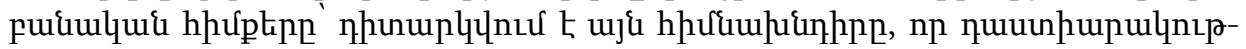

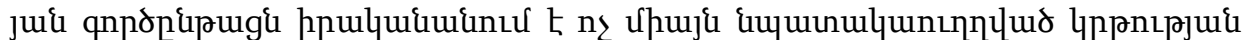

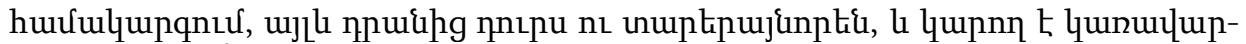

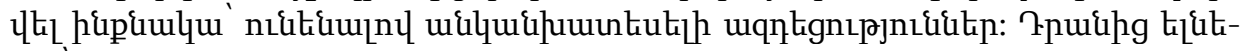

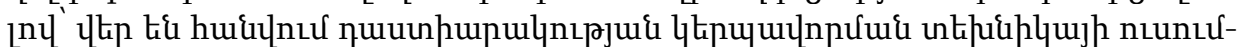

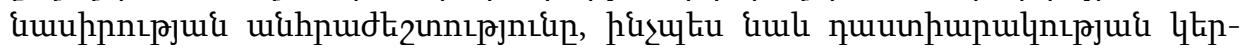

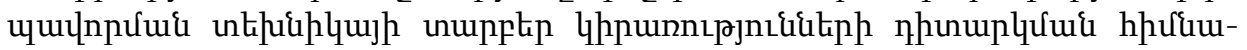

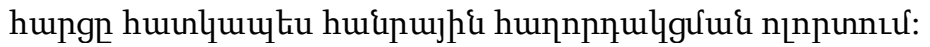

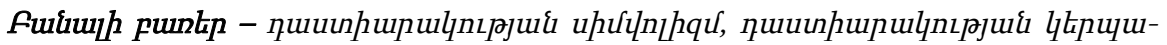

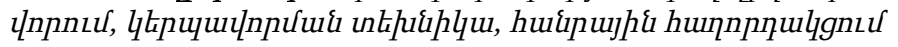

АННА АЛЕКСАНЯН - Техника визуализации воспитания и ее применение в сфере общественной коммуникации - С коммуникативной точки зрения современное воспитание является социальным вызовом, обусловленным социальным взаимодействием, основанном на коммуникационных влияниях, выходящих за рамки современной системы образования. В контексте изменений, происходящих в различных современных социальных процессах, влияющих на становление и развитие личности, особое значение приобретает изучение, выявление и применение нового потенциала воспитания. В статье представлены особенности воспитания в формальной и неформальной образовательных сферах. В статье обсуждается методологическая база для изучения процесса воспитания и рассматривается проблема, заключающаяся в том, что процесс воспитания происходит не только в целевой системе образования, но и самопроизвольно, и может управляться добровольно и с непредсказуемыми последствиями. Исходя из этого выявляется необходимость изучения техники визуализации воспитания, а также поднимается вопрос наблюдения за различными применениями техники визуализации воспитания, особенно в области общественной коммуникации.

Ключевые слова: воспитательная символика, визуализация воспитания, техника визуализации, общественная коммуникация

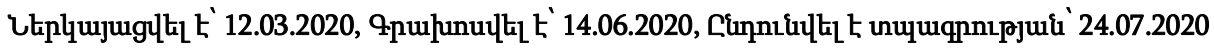




\begin{abstract}
From a communicative point of view, modern education is a social challenge due to social interaction based on communication influences that go beyond the modern education system. In the context of changes taking place in various modern social processes that affect the formation and development of a personality, the study, identification and application of the new potential of upbringing is of particular importance. The article presents the features of education in the formal and informal educational spheres. The article discusses the methodological basis for studying the upbringing process and considers the problem that the upbringing process takes place not only in the target education system, but also spontaneously, and can be controlled voluntarily and with unpredictable consequences. Based on this, the need to study the technique of visualization of education is revealed, and the question of observing various applications of the visualization of education, especially in the field of public communication, is raised.
\end{abstract}

Keywords: upbringing symbolism, visualization of upbringing, techniques of visualization, public communication

\title{
About Authors
}

Anna Aleksanyan - PhD, Associate Professor of the Chair of Educational Sciences, Yerevan State University

E mail: anna.aleksanyan@ysu.am

\section{REFERENCES}

Cooley, C. H. (1909) Social organization: A study of the larger mind. New York, NY: Charles Scribner's Sons. Doi: https://doi.org/10.1037/14788-000

Craig, R. T. (1999) Communication Theory as a Field. Communication Theory, 9 (2), pp. 119161. Doi: https://doi.org/10.1111/j.1468-2885.1999.tb00355.x

Richard, L. L. (1992) The Human Science of Communicology, Duquesne University Press. Isaac, E. C., Deborah Eicher-Catt (2010) Communicology: The New Science of Embodied Discourse. Fairleigh Dickinson Univ Press, 2010.

Adler, A. (1956) The individual psychology: A systematic presentation of selection from his writings. H.L. \& R.R. Ansbacher (Eds.). New York: Basic Books.

Bandura, A (1991) Social cognitive theory of self-regulation. Organizational Behavior and Hman Decision Processes, Hillsdate, pp. 248-287. Doi: https://doi.org/10.1016/0749-

5978(91)90022-L

Fromm, E. (1955) The sane society. New York: Rinehalt.

Sullivan, H.S. (1953) The interpersonal theory of psychiatry. New York: Norton.

Watson D.L. \& Tharp R. G. (1989) Self-directed behavior: Self-modification for personal argument. Pacific Grove, pp. 224-231.

Stolyarenko, A.M. (2006) Obshaya pedagogika, Moscow, YUNITI-DANA, p. 211. 
Komenskii, Y.A. (1955) Izbrannye pedagogicheskie sochineniya, Moscow, Gos. uchebnopedagogicheskoe izdatel'stvo ministerstva prosvescheniya RSFSR.

Rousseau, J.-J. (1979) Emile, or On Education. Trans. Allan Bloom. New York: Basic Books. Tolstoi, L.N. (1955) Sbornik statei. Posobie dlya uchitelya, Moscow, Gos. uchebnopedagogicheskoe izdatel'stvo ministerstva prosvescheniya RSFSR, p. 32.

Maslow, A.A. (1943) Theory of Human Motivation. Psychological Review, Vol. 50, No4, pp. 370-396. Doi: https://doi.org/10.1037/h0054346

Rogers, C. \& Stevens, B. (1967) Person to Person: The Problem of Being Human. Lafayette, CA: Real People Press. Doi: https://doi.org/10.4324/9780203725672

Rogers, C., Lyon, H. C. \& Tausch, R. (2013) On Becoming an Effective Teacher-Personcentered Teaching, Psychology, Philosophy, and Dialogues with Carl R. Rogers and Harold Lyon. London: Routledge.

Fromm, E. (1965) Socialist Humanism, NY: Doubleday.

Fromm, E. (1968) The Revolution of Hope, toward a humanized technology, American Mental Health Foundation.

Fromm E. (1997) On Being Human, Continuum.

Frankl, V. (1988) The Will to Meaning. Foundations and Applications of Logotherapy, New American Library, New York.

Vygotskii, L.S. (2005) Psichologiya razvitiya rebyonka, Moscow, Eskimo.

Piaget, J. (1928) The Child's Conception of the World. London: Routledge and Kegan Paul.

Piaget, J. (1954) The construction of reality in the child New York: Basic Books. Doi:

https://doi.org/10.1037/11168-000

Montessori, M. (1947) Education for a New World. Kalakshetra.

Makarenko, A.S. (1972) Kollektiv i vospitanie lichnosti, Moscow, Pedagogika.

Shtainer, R. (1998) Poznaniya cheloveka i uchebnyi process, Moscow, Parsifal'.

Dewey, J. (1938) Experience and Education, Kappa Delta Pi, N.Y.

Schulz, A. (1962) Symbol, Reality, and Society, in Schulz A. Collected Papers. V.I. The

Problem of Social Reality, Dordrecht, Kluwer Academic Publishers. Doi:

https://doi.org/10.1007/978-94-010-2851-6_11

Blumer, H. (1969) The Methodological Position of Symbolic Interactionism, in Blumer H.

Symbolic Interactionism. Perspective and Method. Berkeley: University California Press, p. 1.

Mead, G. (1934) Mind, Self and Society. From the Standpoint of a Social Behaviorist. Chicago:

The University of Chicago Press, P. 122.

Elias, N. (1991) The Symbol Theory. London, Sage, p. 40.

Turner, R. \& Killian, L.M. (1957) Collective Behavior. Englewood Cliffs, N.J.: Prentice-Hall.

Parsons, T. (1951) The social system, New York, The Free Press, Chapter IX. Expressive

Symbols and the Social System. The Communication of Affect, pp. 384-427.

Holl, K.S. \& Lindsey G. (1999) Teorii Lichnosti, Moscow, EKSMO=PRESS, p. 56. 